\title{
Key Determinants of Acceptance and Use of E-Services Based on Marketing Technology Process
}

\author{
Rosy Anresia Metasari ${ }^{\mathrm{a}} *$ Sujarwoto $^{\mathrm{b}}$ \\ ${ }^{a}$ Bureau of City Management and Environment Jakarta Provincial Government, Jakarta, Indonesia \\ ${ }^{b}$ Department of Public Administration Brawijaya University, Indonesia
}

\section{INFORMASI ART IKEL}

\section{Article history:}

Date submission : 26 March 2019

First revision : 12 April 2019

Accepted: 20 April 2019

Available online: 30 April 2019

Keywords: citizens perceptions, acceptance and use, marketing technology process, e-services

\begin{abstract}
Nowadays, government uses e-services to boost the services for citizen with many endeavours but there are some e-service where the technology did not accommodate or appropriate to citizen needs. In order to improve the service and accomodate the citizen needs, this journal attempts to explore the related key determinants or variables. Exploration of theory is begun from the definition of e-services, the explanation of public choice theory and organizational behaviour theory in public administration until the model of citizen use and acceptance of e-services. Considering the government efforts to introduce the e-services, this model combines Unified Theory of Acceptance and Use of Technology (UTAUT) with the marketing process to seek key determinants from citizen personality, perceptions, and attitude.
\end{abstract}

\section{INTISARI}

Saat ini, pemerintah menggunakan e-services untuk meningkatkan pelayanan kepada masyarakat dengan segala upaya namun terdapat e-services yang teknologinya tidak mengakomodir atau sesuai dengan kebutuhan masyarakat. Dalam rangka meningkatkan pelayanan dan mengakomodasi kebutuhan masyarakat, jurnal ini bermaksud untuk meneliti kunci-kunci penentu atau variablevariabel terkait. Penjelasan teori dimulai dari penjelasan e-services, penjelasan teori pilihan publik dan teori perilaku organisasi dalam administrasi publik sampai model penerimaan dan penggunaan e-services. Mempertimbangkan upaya pemerintah dalam memperkenalkan e-services, model ini menggabungkan Unified Theory of Acceptance and Use of Technology (UTAUT) dengan proses marketing untuk mencari kunci penentu berdasarkan personaliti, persepsi dan sikap masyarakat.

2019 FIA UB. All rights reserved.

\section{Introduction}

Facing the complexity of problems and situations, government evolves to give the best public service to fulfill citizens needs. In the new public management era, government attempts to put business values in order to improve the public services (Abdelsalam et al., 2013:407). In recent years, e-services has an important things as a tool to improve public management (GallegoÁlvarez, et al., 2010:424). E-services is taken to be the ability for citizens to interact with the city via the Internet in either way more sophisticated than a simple email letter to the generic city (or Webmaster) or e-mail address provided at the site (Torres et al, 2005:218).

Meanwhile, in creating technologies or internets, business or government often makes products that do not 
meet the demand (Dohler, 2017). Scholars criticize about public sector carries major risks through private support schemes and public investments, and people are made to adjust to a new technologically without much room for choices of their own (Hollands, 2014:74).

To understand the service is well-performed, exploring the theory from time to time can extend the views and make the right decission. Public choice theory and organizational behaviour theory are the base theory in public administration to know or measure the successfull of public services (Shaw, 2008:4 and Altman et al., 1985:4). Moreover, the organizational behaviour can be seen through understanding individual behaviour by approaching some basic components like personality, perceptions, and attitude (Altman et al., 1985:73).

The way of inidividuals attitude to make decisions and the quality of their choices are mostly influenced by their perceptions (Robbins and Judge, 2013:208). Many arguments discuss the strength and weakness of citizens perceptions as the measurements of the sucessfull of public services, but follows the New Public Management (NPM) philosophy, citizens perceptions would suggest as its main criterion for success (Andrews \& Van De Walles, 2012:7-8).

To improve the using of e-services, the citizens perceptions are needed. Meanwhile, government, as the owner of e-services attempts to introduce it and improve the quality of services for many citizens. According to this, we explores the evolution of citizens perceptions of acceptance and use of e-services with considering the government effort to introduce this service.

\section{Discussion}

\subsection{E-services}

E-services that has been used for government services was defined by many organizations and experts. Some international organizations explained it (as cited in Torres et al., 2005:218) as using of the Internet and the World-Wide-Web for delivering government information and services to citizens. Moreover, an early definition was provided by Kaylor et al (as cited in Torres et al, 2005:218) that e-services that has been used for government services was developed more sophisticated than a simple email letter. This definition was supported by Relyea in 1997 (as cited in Torres et al., 2005:218) where e-services that has been used for government services was similar as a broad recognition of a confluence of information technology (IT) developments and the application and use of these technologies by government entities. Next, the UNESCO (as cited in Al Athmay, 2013:2577) defined e-services as the public sector, with information and communication technologies (ICTs), is used to improve information and service delivery, encourage citizens participation in the decision making process and make government more accountable, transparent and effective.

ICTs have been deeply affecting relationships and the use of e-services is indeed one of the fastest-growing activities on the Internet (Gallego-Álvarez, et al., 2010:424). According to that, for government, e-services has many benefits, like improve public management, simplify and improve transactions between governments and other actors, and remove the barriers of public administration, Furthermore, Torres et al. (as cited in Gallego-Álvarez et al., 2010:424) explained the eservices can change both the delivery of public services and the wider scope of interactions between citizens and governments.

Meanwhile, in creating technologies, government often make products that do not meet the demand (Dohler, 2017). Scholars criticized about public sectors carry major risks through private support schemes and public investments where people are made to adjust to a new technology without much room for choices of their own (Hollands, 2014:74). Adding to that, there are problems like expanding skills gap and 'digital divide' related to how the technologies are distributed and access for everyone with different background and ability and structural issues related to security and ownership of the data and access by third parties (Curwell et al., 2005:61). Majority ICT applications will fail if implemented topdown, while bottom-up development is appropriate for meeting the needs of ICT users (Gramatikov, 2003:8).

Facing these problems, electronic services must follow the actual and precise needs of citizens to perform better (Lee and Hyejung, 2014:101). Understanding the citizen perception can be seen through the New Public Management philosophy where satisfying citizens' needs is pursued to make the efficient and effective services (Gallego-Álvarez et al., 2010:424).

\subsection{Public Choice Theory and Organizational Behaviour Theory in Public Administration}

In new public management, government needs to be dynamic with taking into account business administration principles and applying them to public settings (Abdelsalam et al., 2013:407). These management principles are used by governments around the world to face the complexity of sustainable development and some priorities issues by renewing their public administration and focusing on citizens and emphasizing performance enhancement (Barbosa et al., 2013:744). In addition, a scholar explained assessing administration performance efficiency must involve the citizens (Denhardt \& Denhardt, 2007:8). Moreover, these principles view the public services as an accumulation from the pursuit of private interests and the government as a facilitator of individual choice using market techniques (Brainard \& McNutt, 2010:838). This idea may be understood as the 
convergence of principles that rooted in rational/public choice theory (Barbosa et al., 2013:744 and Brainard \& McNutt, 2010:838).

Public choice theory grows with the base assumption that human beings are rational economic actors driven by competitive self-interest (Terry, 1998:196). Nowadays, public choice theory is used for many functions where one of them is to evaluate or analyse the policy related to the public services (Shaw, 2008:4). The first assumption is the characteristics of individuals who are selfinterested and rational always want to attain the best values with low effort in services (Ostrom \& Ostrom, 1971:206). The second one is public choice focusing on public service which are provided for all citizens (Denhardt \& Denhardt, 2007:10). Thus, government must focus on the act individuals and groups in effort to maximize their own interests and on the way that market mechanism both influence and respond to individual choices (Denhardt \& Denhardt, 2007:11). It is valuable to focus on citizens's needs to change the efficiency paradigm of the public services and to promote more efficient and less costly processes (Barbosa et al., 2013: 745). How to understand citizens needs or interest and their act in public services can be understood through organizational behaviour theory.

Organizational behaviour is a study concerned with describing, understanding, predicting, and controlling human behaviour in an organizational environment (Altman et al., 1985:4). The base element of this theory is the individual, a very complex being whose needs, drives, and motives merit close analysis (Altman et al., 1985:58). Understanding individual behaviour can be approached by some basic components like personality, perceptions, and attitude (Altman et al., 1985:73).

The way of inidividuals attitude to make decisions and the quality of their choices are mostly influenced by their perceptions (Robbins and Judge, 2013:208). Their attitudes and their perceptions usually consistency where if inconsistencies develop people can change their attitudes (Altman et al., 1985:102). In organizational behaviour, individuals's decision-making are an important part (Robbins and Judge, 2013:208). Research can measure their attitudes by questionnaires or interviews or both (Altman et al., 1985:102).

Furthermore, people act or make an decision are difference ones to others where influence not only by internal factors, like their personality, gender, mental ability and cultural difference but also by organizational constraints, like performance evaluation, system, formal regulation and historical precedents (Robbins and Judge, 2013:218-222). Facing the problems in conflicts situation, managers can use power tactics or policies to shape people behaviour and attitudes through their perceptions (Robbins and Judge, 2013:452, 600).

\subsection{Citizen Perceptions}

Based on Robin and David (CAFRAD, 1998:5), when individuals role as citizens, they have certain rights or entitlements from government but as client or customer of the government, individuals do not share any common purpose with the country and are acting on individual basis seeking personal advantage. Citizens also have many kinds, like rural and urban citizens, rich and poor citizens or elite and common people where every person may have different or varying perceptions or needs (CAFRAD, 1998:5).

Perception is a process where individuals organize and interpret their sensory impressions to explain about their environment beside their interpretation can somehow be different to objective reality (Robbins and Judge, 2013:200). Three factors that influence perceptions are factors in the perceiver (attitudes, motives, interest, experiences and expectations), factors in the situation (time, work setting and social setting) and factors in the target (novelty, motion, sounds, size, background, proximity and similarity) (Robbins and Judge, 2013:201).

One one said, Banducci, et al (as cited in Andrews \& Van De Walles, 2012:7) explained that political research has been quite ambivalent towards using citizens opinions about government because citizens do not always appear to be well informed. Argued to that, James (as cited in Andrews \& Van De Walles, 2012:7) explained it would be incorrect to consider citizens perceptions as the ultimate performance evaluation, because citizens do normally not evaluate performance based on a full set of information, but use shortcuts or cues. In addition, Cowell, et al. and Van de Walle \& Bouckaert (as cited in Andrews \& Van De Walles, 2012:7) argued the relationship between improved government performance and more positive public perceptions is far from straightforward. Moreover, Lauer Schachter (as cited in Andrews \& Van De Walles, 2012:7) said that there is an active debate about the differences between using objective or subjective evaluations, or between agency- and citizen-generated data. Next, James, Van de Walle \& Van Ryzin (as cited in Andrews \& Van De Walles, 2012:7) argued that content and methodological factors that determine these perceptions.

On the other side, Kelly \& Swindell (as cited in Andrews \& Van De Walles, 2012:7) said that using citizens perceptions has become increasingly common in public administration research to assess the performance of public services. Adding to that, Charbonneau \& Van Ryzin, Immerwahr \& Altman, and Swindell \& Kelly (in Andrews \& Van De Walles, 2012) argued citizens evaluations have been proven to be quite useful and reliable to evaluate public services. An additional 
advantage of using citizens perceptions is often one of the few ways available to assess service outcomes rather than service outputs. Using citizens perceptions also helps overcome some criticism about the artificial selection of sets of objective output and outcome indicators in models (Andrews \& Van De Walles, 2012:7).

Another advantage of using citizens perceptions is illustrating the trade-offs between the different values and effects of managerial practices in the public sector should be made with reference to citizens, whereas such choices are made by the policy-maker and researcher when 'objective' performance indicators are used (Andrews \& Van De Walles, 2012:8). Their perceptions of the role of public administration can become an engine of growth or facilitator of growth (CAFRAD, 1998:4). Hence, the government needs to consider citizens's perceptions as users of e-services. There is a complete model to measure people perceptions about technology which is Unified Theory of Acceptance and Use of Technology (UTAUT).

\subsection{UTAUT}

The process of people using a technology is initially based on their reactions to the technology which will affect their intentions and reflect the actual conditions (Venkatesh et al., 2003:427).

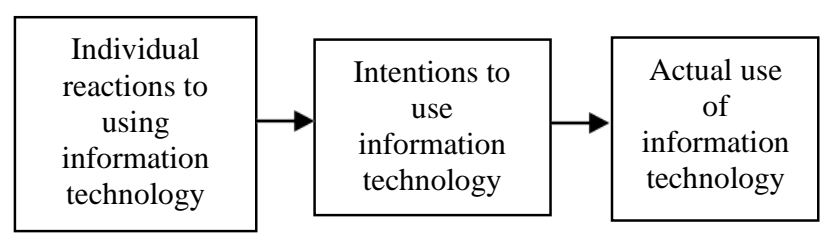

Figure 1 Basic Concept Underlying

User Acceptance Models

Source: Venkatesh et al, 2003
Venkatesh et al. (2003) proposed a new citizen perception of technology use model based on 8 previous models: the theory of reasoned action, the technology acceptance model, the motivational model, the theory of planned behaviour, a model combining the technology acceptance model and the theory of planned behaviour, the model of PC utilization, innovation diffusion theory, and the social cognitive theory (Venkatesh et al., 2003:425). The model named Unified Theory of Acceptance and Use of Technology (UTAUT), as shown in the figure 1 , is determined by 4 factors which are performance expectancy, effort expectancy, social influence, and facilitating conditions (Venkatesh et al., 2003:447).

UTAUT is simillar to the organizational behaviour where the individual attitude can be seen through the internal factors which are perceptions and personalities and the external factors. In this theory, the attitude is the actual use, the perceptions are performance expectancy, effort expectancy, and social influence, the personalities are gender, age, and experience and the external factor is the facilitating conditions. Citizen perception of performance expectancy, effort expectancy, and social influence blend into the behavioural intention. Then, the behavioural intention joins the personalities and the external factor affect to the attitude. From the explanation above, the Unified Theory of Acceptance and Use of Technology (UTAUT) can be captured into the Figure 2 below (Venkatesh et al., 2003:447).

More than 15 years, this theory has been used for many researchs and many objects of technologies. With various environments, this theory also evolves into many formulas combining with other related theories (Michael et al, 2015:445).

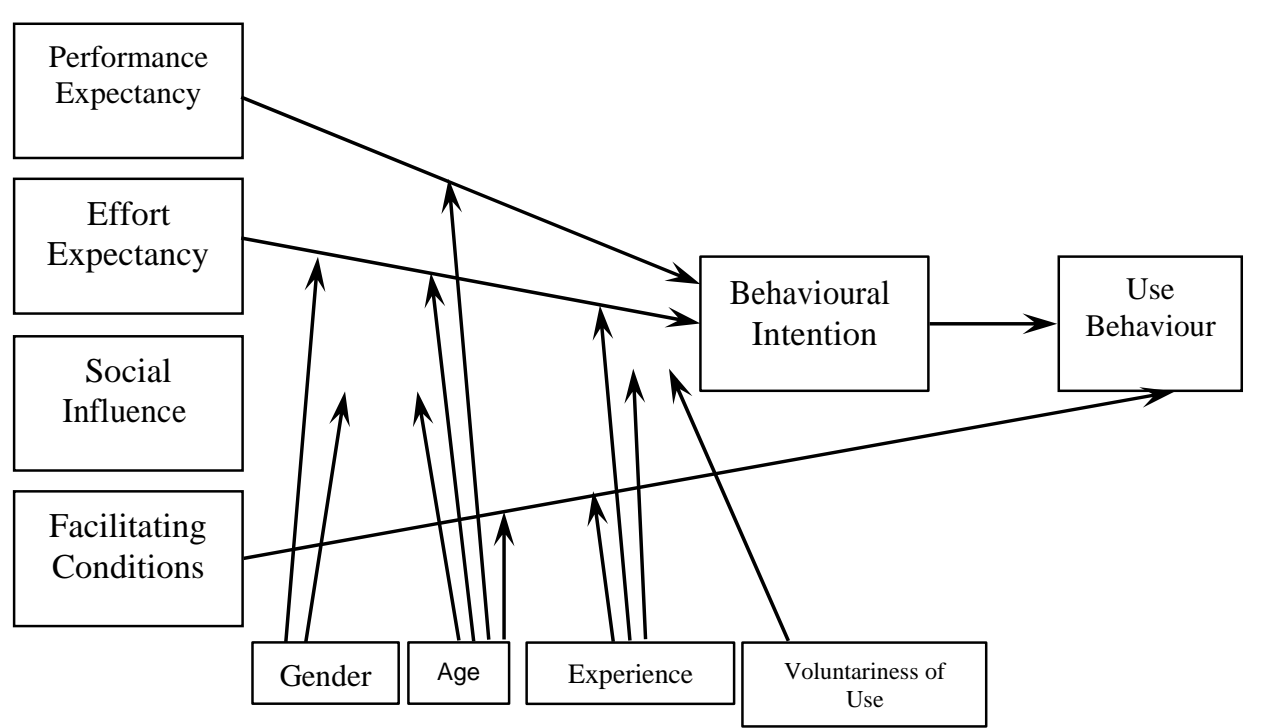

Figure 2 Model of Unified Theory of Acceptance and Use of Technology (UTAUT) Source: Venkatesh et al, 2003 
In this case, e-services as public services, is provided and introduced by government so the governmet efforts to introduce this service directly and indirectly affect to the citizens perception. It is crucial for the new product launch to the market to be planned from the begining, and the success of the product will depend on how well marketing managers arrange it (Chan et al., 2010). According to that, we can combine the UTAUT with government efforts through the marketing process.

\subsection{Marketing Process}

Introduction of new technology is something important where if we make mistakes the consequences are invariably fatal (Easingwood and Koustelos, 2000:27). How to induce the market to use a new technology is generally comprised of four steps below (Easingwood and Koustelos, 2000:27):

a) Market Preparation Step

The first step to get the market ready for the new technology by building awareness and forming relationships (Easingwood and Koustelos, 2000:27). It can be started from the plan to cooperate with the same model technology and plan to introduce and educate how to use the technology for the market (Easingwood and Koustelos, 2000:27-28).

b) Targeting Step

The second step, after planning the market is know who the user "will be" (Easingwood and Koustelos, reluctant ones (Easingwood and Koustelos, 2000:2931).

c) Positioning Step

The next step in the introduction of new technology which is an important step like market preparation clarifies the new technology (Easingwood and Koustelos, 2000:31). Positioning can be measured by tangible or intangible variables to make the product known by society in terms of technology, functions, or brand (Easingwood and Koustelos, 2000:31).

d) Execution Step

The last step to measure the using of new technology is execution, designed to trigger a positive purchase decision (Easingwood and Koustelos, 2000:32). Execution is the action to communicate the generic benefits of new technology or to establish a brand name and competitive advantage of well-known technology (Easingwood and Koustelos, 2000:32).

From the explanation above, we can capture the four steps in marketing technology process in the Figure 3 (Easingwood \& Koustelos, 2000:27).

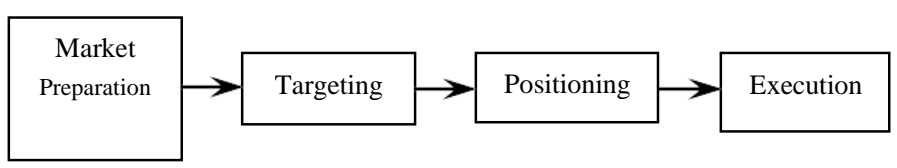

Figure 3 Process of Launching New Technology Source: Easingwood \& Koustelos, 2003

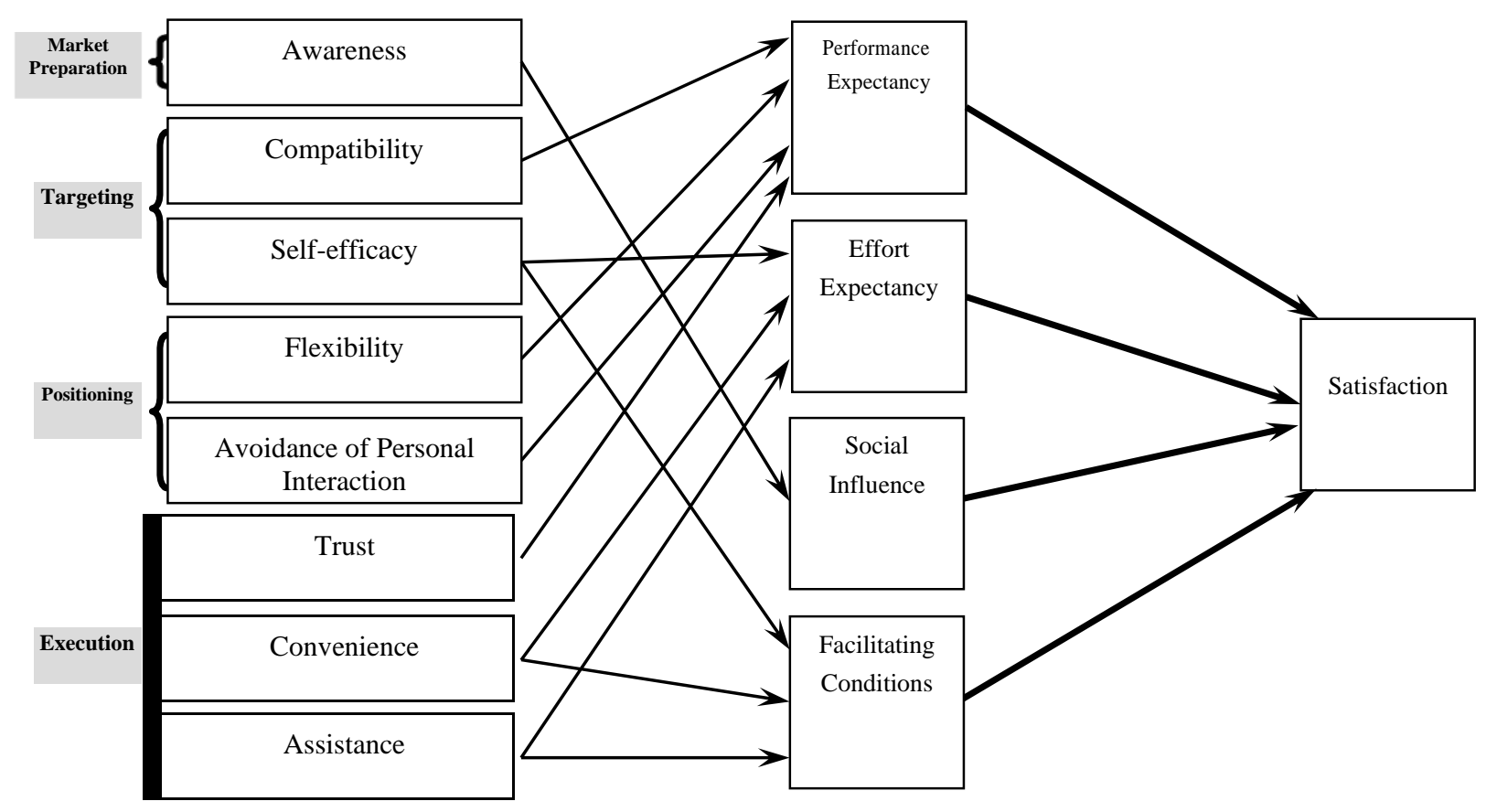

Figure 4 Satisfaction based on Marketing Technology Process Source: Chan et al., 2010

2000:29). By understanding the user type, the producer can choose the best option for marketing where there are many kinds of consumers like the ones who already understand the technology, daily users or

\subsection{Citizen Perceptions Due To Marketing Process}

Following the marketing technology process, we can breakdown the process which affect to the citizens perception into the antecedent variables of UTAUT. 
Modeling the antecedents can help identify interventions to ascertain the acceptance levels and effective use of a technology and to provide a smart way into services management (Chan et al., 2010). In order to identify relevant antecedents of core constructs in general models and consider the launch stage, Chan et al. (2010) proposed a new model to analyze citizens perceptions in satisfaction of new e-services by combining the UTAUT and marketing technology process (Chan et al., 2010). This model used the acceptance and use of new technology for citizens with some modifying variables into the diagram above (figure 4).

\subsection{Key Determinants of Acceptance and Use of E- Services based on Marketing Technology Process}

Based on the Chan Model, we can combine the citizens perceptions of acceptance and use of new technology with the antecedent variables in marketing technology process. The citizens perceptions can be divided into predictor variables, moderator variables, and outcome variables.

Predictor variables are the citizens perceptions due to marketing technology process. Predictor variables are awareness, compatibility, self-efficacy, flexibility, avoidance of personal interaction, trust, convenience, and assistance variables. Moderator variables are the citizens personalities consisting of gender, age, and experience variables. Outcome variables are the citizens perceptions due to the UTAUT, the external factor and the citizen attitude. Outcome variables are performance expectancy, effort expectancy, social influence, facilitating conditions, behaviour intention, and use behaviour variables. The diagram is captured below:
According to the diagram above, the explanation about every variable and each hypothesis in conceptual framework is below:

a) Predictor Variables

Citizens perceptions due to marketing technology process are explained into 4 steps below:

1. Market Preparation Step

In providing ICT, the government is the only provider without competitors; hence, the important thing of this step is increasing citizens awareness (Chan et al., 2010:525-526). Raising citizens awareness can be achieved by various media where the effect can create normative beliefs, which citizens with self-awareness will introduce to others (Chan et al., 2010:525-526).

- Hence, Awareness will positively associate social influence for using e-services technology.

In initial government's technology establishment, awareness can be achieved through introducing it in various media by government, thus directly creating normative beliefs or self-awareness about the technology (Chan et al., 2010:526). The indicators in Chan et al. research follow Charbaji and Mikdashi research where focusing on the environment supports the e-services and governments effort to improve citizen's lives (Charbaji \& Mikdashi, 2003:79; Chan et al., 2010:545). The indicators are the existence of information, government efforts and creating self-awareness (Charbaji \& Mikdashi, 2003:80 and Chan et al., 2010:545).

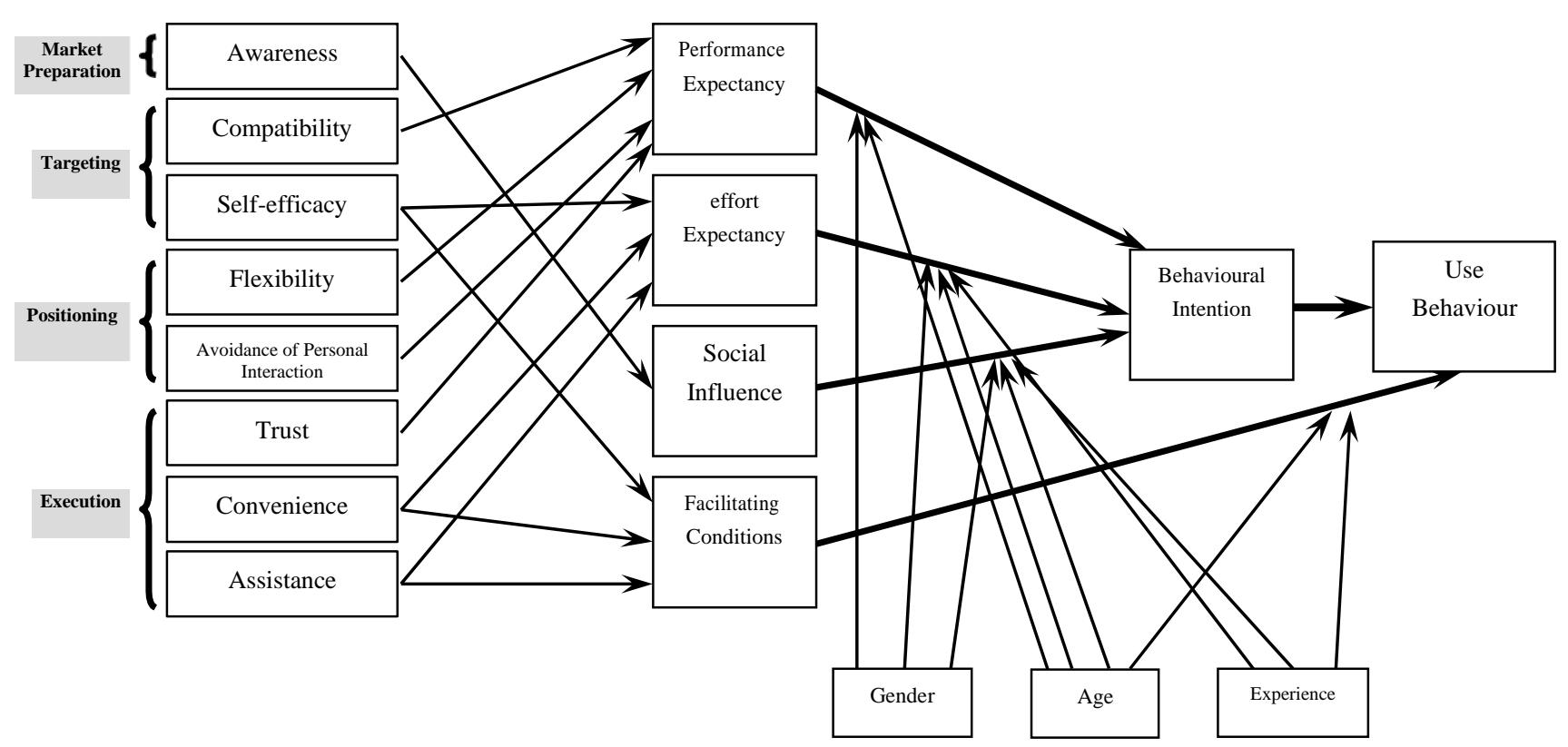

Figure 5 UTAUT based on Marketing Technology Process Source: Analytical result, 2018 


\section{Targeting Step}

To provide ICT like e-services, those who easily understand the applications or the web are the ones who already use the same technology. Understanding citizens as users can be attained by knowing their compatibility and self-efficacy (Chan et al., 2010:526). Compatibility is the willingness of the user to use the technology because it is suitable for their daily activities or lifestyle or expectation and this compatibility will affect the expectation of accessing government services which match to their needs (Chan et al., 2010:526-527). Self-efficacy is the ability of users to use the technology easily (Chan et al., 2010:527). A citizen who has a self-efficacy will use the technology if the effort is only little (Chan et al., 2010:527). Furthermore, with self-efficacy citizens also hope the government will support the facilitation to encourage the using (Chan et al., 2010:527).

- Hence, Perceived compatibility will positively associate performance expectancy toward e-services technology, Self-efficacy will positively associate effort expectancy toward e-services technology, and Self-efficacy will positively associate facilitating conditions for using e-services technology.

In the second stage, some people align it to their values or aspects in life, some people who advance in technology think it will fulfill their expectations or needs and the others think it will suitable for their daily lifestyle (Easingwood and Koustelos, 2000:27-

28, Chan et al., 2010:526). The indicators of compatibility in Chan et al. research follow Moore and Benbasat research (Chan et al., 2010:545). Compatibility is citizens perceptions about e-services where for some degree as being consistent with existing values, needs, and past experiences (Moore \& Benbasat, 1991:195).

Self-efficacy in targeting stage follows Compeau and Higgins research (Chan et al., 2010:545). The definition of self-efficacy is the capability to use the technology where people with high self-efficacy may expect to perceive themselves to use it and the ones with low self-efficacy need more support (Compeau \& Higgins, 1995:192). This variable related to organizational support for computer users in equipment selection, hardware difficulties, software difficulties, and specialized instruction by the helper (Compeau \& Higgins, 1995:197). The indicators of this variable are the availability by calling, self-help information, and the assistance to show how to use (Compeau \& Higgins, 1995:211).

3. Positioning Step

In using ICT like e-services, citizens hope for the flexibility and avoidance of personal interactions (Chan et al., 2010:527). Flexibility is the skill of government to provide many alternative functions of the ICT which is the citizen's will then this flexibility will affect the performance expectancy (Chan et al., 2010: 528). Meanwhile, avoidance of personal interaction is the improvement that citizens hope where they unnecessary to meet the public servants in enjoying the facilities (Chan et al., 2010: 528).

From the explanation, we can say Flexibility will positively associate performance expectancy toward e-services technology, and Avoidance of personal interaction will positively associate performance expectancy toward e-services technology.

In positioning stage, flexibility follows Wixom and Todd research where it defines into the way the technology system adapts to change due to demands of the user (Chan et al., 2010:545; Wixom \& Todd, 2005:90). The indicators of this variable are the adaptation to meet the variety of needs, flexibility adjusts to new demands, and versatile deal with arising needs (Wixom \& Todd, 2005:93).

Generally, many scholars said society prefer selfservice over face to face service because of not only the time savings and increased personal control but also getting effectiveness and efficiency (Chan et al., 2010:528). Avoidance of personal interaction in the third stage follow Gilbert et al. research and Meuter et al research where the new technology allows citizens to access and use the services without interaction to service personnel or members of the service provider'staff even anyone (Chan et al., 2010:528; Gilbert, 2004: 290 and Meuter et al., 2000:55). The indicators of this variable are the benefit of do not to interact with anyone, have no interaction to civil servants, and enabling service by myself.

4. Execution Step

$\mathrm{Yu}$ (as cited in Chan et al., 2010:528-529) explained e-services has increased use of government services through increased availability and convenience, but it has also raised citizens' concerns about security and privacy. Furthermore, Venkatesh et al. (as cited in Chan et al., 2010:529) explained individual's perceptions regarding the availability of supporting resources will affect the using of technology. These facts suggest that variables relevant to the execution step are trust, convenience, and assistance (Chan et al., 2010:529). Trust is the condition that makes people want to use the new technology because of the dream of the ICT (Chan et al., 2010: 529). Meanwhile, convenience is the pleasure of using new technology which affects the effort expectancy in terms of less effort, and affects the facilitation expectancy in that government provides a service to make them satisfied (Chan et al., 2010: 529-530). Assistance is the support network for 
using new technology which facilitates less effort in the use of technology (Chan et al., 2010: 530).

From the explanation, we conclude that Trust will positively associate performance expectancy toward e-services technology, Convenience will positively associateseffort expectancy toward e-services technology, Convenience will positively associate facilitating conditions for using e-services technology, Assistance will positively associate effort expectancy toward eservices technology, and Assistance will positively associate facilitating conditions for using e-services technology.

In this final stage, trust is something important where the trustee/ government and the trustor/user do not meet physically (Chan et al., 2010:529). Moreover, Pavlou and Fygenson (as cited in Chan et al., 2010:529) explained due to the situation, trustor gives trust to the trustee. Disposition to trust means a general tendency to trust others, which can also influence an individual's beliefs and intentions towards a Web-based application (McKnight et al., 2002:336). The indicators of this variable follow McKnight et al. research which are competence, benevolence, and integrity (McKnight et al., 2002:355).

Convenience, in the execution step, is something users receive in self-service technology related to accessibility and availability, where it defines the ability to receive the service, how and when the individual wants toreceive it, at their own convenience (Meuter et al., 2000:59 and Gilbert et al., 2004:290). The indicators of this variable are using whenever the user wants or the user's convenience of "whenever", wherever the user wants or the user's convenience of "whereever", and the user convenient feeling or the user's feeling of convenience (Meuter et al., 2000:56 and Chan et al., 2010:545).

Assistance is the ease of getting help on problems that user face (Goodhue, 1998:132 and Karimi et al., 2004:191). In electronic services, Barua et al. and Deiese et al. (as cited in Chan et al., 2010:530) explained the assistance needs to be real-time, ondemand, easy to follow knowledge base or experienced service. The indicators of this variable are the expectation of help, ease of getting assistance and expectation of clear instructions (Chan et al., 2010:545).

b) Moderator Variables

Citizen personalities are explained by gender, age, and experience. The gender divides into female and male. The age is the number of year of users's life. The experience is the users's experience of using eservices. Moderator variables affect to the outcome variables into below:
- The degree of performance expectancy is based on gender and age where younger men are hoped for the high expectation (Venkatesh et al., 2003:449450);

- The degree of effort expectancy is based on gender, age, and experience where older women with low experience are hoped for the high expectation (Venkatesh et al., 2003:468);

- The degree of social influence is based on gender, age, voluntariness, and experience where older women with low experience are hoped for the high expectation (Venkatesh et al., 2003:453); and

- The degree of facilitating conditions is based on age and experience where older people are needed help in using an information technology (Venkatesh et al., 2003:454-455).

c) Outcome Variables

Outcome variables are 4 citizens perceptions due to the UTAUT (performance expectancy, effort expectancy, social influence, and behaviour intention variables), the external factor (facilitating conditions variable) and the citizen attitude (use behaviour variable).

\section{Performance Expectancy}

Performance expectancy is the reason an individual uses technology related to the job or individual goals (Venkatesh et al., 2003:448-449). This variable has two indicators which are relative advantage and outcome expectations (Venkatesh et al., 2003:461).

\section{Effort Expectancy}

Effort expectancy is the perceived ease of using the technology or how easily the technology can be used with minimum effort (Venkatesh et al., 2003:451). This variable has two indicators which are perceived ease of use and ease of use(Venkatesh et al., 2003:461).

\section{Social Influence}

Social influence is the impact of social norms or social situation of using the technology to individual perceived (Venkatesh et al., 2003:451-452). This variable has two indicators which are the subjective norm and social factors (Venkatesh et al., 2003:461). 4. Facilitating Conditions

Facilitating condition is the condition of organizational and technical infrastructure which endorses the using of technology and deprives deterrent (Venkatesh et al., 2003:453). This variable has two indicators which are perceived behaviour control and facilitating conditions (Venkatesh et al., 2003:461).

\section{Behavioural Intention}

Behavioural Intention is the user'subjective possibility that he will perform the behaviour in question (Alshehri, 2013:91). This variable has three 
indicators, intention, prediction, and planned use of Qlue Application (Alshehri, 2013:91).

\section{Use Behaviour}

Use behaviour of e-gov services is the actual use of a specific system, in this case, Qlue Application (Alshehri, 2013: 91). This variable has three indicators, frequently using, regular basis using, and using for fulfilled needs (Alshehri, 2013: 240-241).

\section{Conclusion}

Electronic services is the government service for citizen in many purposes to make government more accountable, transparent and effective (Al Athmay, 2012:2577). In the development of this services, it must follow the actual and precise needs of citizens to perform better (Lee and Hyejung, 2014:101). These requiremets are associated with NPM philosophy where satisfying citizens' needs is pursued to make the efficient and effective services (Gallego-Álvarez et al., 2010:424).

From the NPM principles, the public services is the accumulation from the pursuit of private interests and the government as a facilitator of individual choice using market techniques (Brainard \& McNutt, 2010:838). Understanding individual behaviour can be approached through organizational behaviour theory by some basic components like personality, perceptions, and attitude (Altman et al., 1985:73).These components are connected in UTAUT.

Furthermore, e-services, as public services, is provided and introduced by government so the governmet efforts to introduce this service directly and indirectly affect to the citizens perception. Understanding the comprehensive connected, UTAUT with government efforts through the marketing process becomes the model to seek the citizen use and acceptance to e-services through their perceptions and personality.

Predictor variables are the citizens perceptions due to marketing technology process. Predictor variables are awareness, compatibility, self-efficacy, flexibility, avoidance of personal interaction, trust, convenience, and assistance variables. Moderator variables are the citizens personalities consisting of gender, age, and experience variables. Outcome variables are 4 citizens perceptions due to the UTAUT (performance expectancy, effort expectancy, social influence, and behaviour intention variables), the external factor (facilitating conditions variable) and the citizen attitude (use behaviour variable).

\section{References}

Abdelsalam, H. M., Reddick, C. G., Gamal, S., \& Alshaar, A. (2013). Social Media In Egyptian Government Websites: Presence, Usage, And Effectiveness. Government Information Quarterly,
Vol. 30(4), pp.406-416. $\quad$ DOI:
10.1016/j.giq.2013.05.020.

Al Athmay A. A. R. A. (2013). Citizens' Perceptions towards e-Governance: Field Study. International Journal of Humanities and Social Science, Vol. 7, No. 9, pp.2576-2584.

Alshehri, M. A. (2013). Using the UTAUT Model to Determine Factors Affecting Acceptance and Use of E-government Services in the Kingdom of Saudi Arabia. Thesis (PhD Doctorate), Griffith University, Brisbane.

Altman, S., Valenzi, E., \& Hodgetts, R. M. (1985). Organizational Behaviour: Theory and Practice. Florida: Academic Press, Inc.

Andrews R. \& Van De Walle S. (2012). New Public Management and Citizens' Perceptions of Local Service Efficiency, Responsiveness, Equity and Effectiveness. COCOPS Working Paper No. 7. Available at https://lirias.kuleuven.be/bitstream/123456789/56 2051/1/COCOPS_workingpaper_No7.pdf [Accessed on april 1, 2018].

Barbosa, A. F., Pozzebon, M., \& Diniz, E. H. (2013). Rethinking E-Government Performance Assessment From A Citizen Perspective. Public Administration, Vol. 91(3), pp.744-762. DOI: 10.1111/j.1467-9299.2012.02095.x.

Brainard, L. A., \& McNutt, J. G. (2010). Virtual Government-Citizen Relations: Informational, Transactional, or Collaborative?. Administration \& Society, Vol. 42(7), pp.836-858. DOI: 10.1177/0095399710386308.

CAFRAD (African Training and Research Centre in Administration for Development). (1998). Citizens'Perception of the Role of Public Administration and their Assessment on the Public Services. Available at http://unpan1.un.org/intradoc/groups/public/docu ments/cafrad/unpan006345.pdf [Accessed on May 3, 2018].

Chan, F. K. Y., Thong, J. Y. L., Venkatesh, V., Brown, S. A., Hu P.J., \& Tam, K. Y. (2010). Modeling Citizen Satisfaction with Mandatory Adoption of an E-Government Technology. Journal of the Association for Information Systems, Vol. 11(10), pp.519-549.

Charbaji, A., \& Mikdashi, T. (2003). A Path Analytic Study of The Attitude Toward E-Government in Lebanon. Corporate Governance, Vol. 3, No. 1, pp.76-82.

Compeau, D. R., \& Higgins, C. A. (1995). Computer Self-Efficacy - Development of a Measure and Initial Test. MIS Quarterly, Vol. 19, No. 2, pp.189211. 
Curwell S., Deakin M., Cooper I., Paskaleva-Shapira K., Ravetz J. \& Babicki D. (2005). Citizens' Expectations of Information Cities: Implications for Urban Planning And Design. Building Research \& Information, Vol. 33, No.1, pp.55-66. DOI: 10.1080/0961321042000329422.

Denhardt, J. V., \& Denhardt, R. B. (2007). The New Public Service: Serving, Not Steering. New York: M. E. Sharpe, Inc.

Dohler, M. (2017). What Do You Know About The Internet of Things?. In Dohler M., The Internet of Things. Available at https://www.futurelearn.com/courses/internet-ofthings/5/steps/141702/questions/4) [Accessed on July 11, 2018].

Easingwood, C., \& Koustelos, A. (2000). Marketing High Technology: Preparation, Targeting, Positioning, Execution. Business Horizons, Vol. 43(3), pp.2734.

Gallego-Álvarez, I., Rodríguez-Domínguez, L., \& García-Sánchez, I. M. (2010). Are Determining Factors of Municipal E-government Common to a Worldwide Municipal View? An Intra-Country Comparison. Government Information Quarterly, Vol. 27(4), pp.423-430.

Gilbert, D., Balestrini, P., \& Littleboy D. (2004). Barriers and Benefits in the Adoption of E-government. International Journal of Public Sector Management, Vol. 17, No. 4, pp.286-301.

Goodhue, D. L. (1998). Development and Measurement Validity of a Task-Technology Fit Instrument for User Evaluations of Information Systems. Decision Sciences, Vol. 29, No. 1, pp. 105-138.

Gramatikov, M. (2003). Data Mining Techniques and The Decision Making Process In The Bulgarian Public Administration. NISP Acee Concerence, Bucharest, Romania.

Hollands, R. G. (2014). Critical Interventions Into The Corporate Smart City. Cambridge Journal of Regions, Economy and Society, Vol. 8, Issue 1, pp.61-77.

Karimi, J., Somers, T. M., \& Gupta Y. P. (2004). Impact of Environmental Uncertainty and Task Characteristics on User Satisfaction with Data. Information Systems Research, Vol. 15, No. 2, pp.175-193.

Lee, Jungwoo., and Hyejung, Lee. (2014). Developing and Validating a Citizen-Centric Typology for Smart City Services. Government Information Quarterly. Vol. 31, pp.S93-S105.

McKnight, D. H., Choudhury, V., \& Kacmar, C. (2002). Developing and Validating Trust Measures for Ecommerce: An Integrative Typology. Information Systems Research, Vol. 13, No. 3, pp.334-359.
Meuter, M. L., Ostrom A. L., Roundtree R. I., \& Bitner M. J. (2000). Self-service technologies: Understanding customer satisfaction with technology-based service encounters. Journal of Marketing, Vol. 64, No. 3, pp.50-64.

Michael D Williams, Nripendra P Rana, \& Yogesh K Dwivedi. (2015). The Unified Theory of Acceptance and Use of Technology (UTAUT): a Literature Review. Journal of Enterprise Information Management, Vol. 28(3), pp. 443 488.

Moore, G. C., \& Benbasat, I. (1991). Development of an Instrument to Measure The Perceptions of Adopting an Information Technology Innovation. Information Systems Research, Vol. 2, No. 3, pp. 192-222.

Ostrom V., \& Ostrom, E. (1971). A Different Approach to the Study of Public Administration. Public Administration Review, Vol. 31(2), pp.203-216.

Robbins S. P. \& Judge T. A. (2013). Organizational Behaviour. London: Pearson Education Limited.

Shaw, J. S. (2008). Public Choice Theory. St. Kliment Ohridski University Press, Sofia, Bulgaria.

Terry, L. D. (1998). Administrative Leadership, NeoManagerialism, and the Public Management Movement. Public Administration Review, Vol. 58(3), pp.194-200.

Torres L, Pina V. T., \& Acerete B. (2005). E-government Developments on Delivering Public Services Among EU Cities. Government Information Quarterly, Vol. 22(2), pp.217-238.

Venkatesh, V., Morris, M. G., Davis, G. B., \& Davis, F. D. (2003). User Acceptance of Information Technology: Toward a Unified View. MIS Quarterly, Vol. 27(3), pp.425-478.

Wixom, B. H., \& Todd, P. A. (2005). A Theoretical Integration of User Satisfaction and Technology Acceptance. Information Systems Research, Vol. 16, No. 1, pp.85-102. 